\title{
PEMODELAN UML UNTUK APLIKASI MANAJEMEN KEUANGAN
}

\author{
OLEH: \\ WALHIDAYAT \\ Program Studi , Manajeman Informatika, UNIKS, Kuantan Singingi \\ Email : walhidayat82@gmail.com
}

\begin{abstract}
The development of mobile information systems with dynamic track and a variety of business needs, in order to be aligned with that goal then a computerized concept is needed. Periodically, the company has always issued financial statements that were made by the accounting department and given to the parties concerned, ie the government, creditors, owners and the management company itself. There are plenty of financial statements issued by the company, but that is commonly used is: Income Statement, Balance Sheet, Cash Flow Statement. Based on the analysis results, it can be seen that the system is feasible to be implemented on the Personal Software for purposes of financial management today is an electronic accounting system (E-Accounting System) using a variety of features that can be used in accordance with its function, and a variety of modeling software requirements this can be used in modeling with UML method.
\end{abstract}

Keywords: Financial Management, UML Modeling, e-Accounting System, Personal Software, Design and Analyzing

\section{A. PENDAHULUAN}

Pada era komputerisasi dewasa ini perkembangan sistem informasi bergerak dengan dinamis mengikuti perkembangan kebutuhan, dengan berbagai kebutuhan bisnis ataupun personal yang memerlukan ekspektasi yang tinggi agar dapat selaras dengan tujuan tersebut maka suatu konsep komputerisasi sangat dibutuhkan.

Untuk menggambarkan berbagai proses dalam perancangan dan pengembangan aplikasi dibutuhkan suatu konsep pemodelan yang dapat menggambarkan secara detail proses - per proses yang dijalani dari tahapan tersebut, pemodelan ini nantinya dapat menyederhanakan defenisi dari keseluruhan sistem informasi yang ditawarkan.

UML (Unified Modeling Language) adalah sebuah bahasa yang berdasarkan grafik / gambar untuk memvisualisasi, menspesifikasikan, membangun, dan pen-dokumentasi-an dari sebuah sistem pengembangan software berbasis OO (Object-Oriented). UML sendiri juga memberikan standar penulisan sebuah sistem blue print, yang meliputi konsep bisnis proses, penulisan kelas-kelas dalam bahasa program yang spesifik, skema database, dan komponenkomponen yang diperlukan dalam sistem software (http://www.omg.org). 


\section{B. RUMUSAN MASALAH}

1. Bagaimana menggambarkan pemodelan untuk pengembangan pada personal software yang berhubungan dengan manajemen keuangan skala usaha tertentu menggunakan metode Unified Modelling Language (UML) yang mampu mempermudah dalam penelaahan berbagai kemungkinan.

2. Bagaimana mendesain sebuah sistem sehubungan dengan pengembangan personal software untuk menyelasaikan masalah pengelolaan keuangan dan dalam pembuatan piranti lunak tersebut.

3. Bagaimana memanfaatkan Unified Modelling Language (UML) untuk memberikan informasi sehingga berbagai kriteria yang dibutuhkan dalam hal perancangan dan pembuatan aplikasi sesuai pesanan akan lebih memenuhi berbagai ketentuan dari pengguna.

\section{TINJAUAN TEORITIS}

\section{Sistem Pengolahan Transaksi}

Komunikasi data adalah merupakan bagian dari telekomunikasi yang secara khusus berkenaan dengan transmisi atau pemindahan data dan informasi diantara komputer - Komputer dan piranti-piranti yang lain dalam bentuk digital yang dikirimkan melalui media komunikasi data. Data berarti informasi yang disajikan oleh isyarat digital.

Komunikasi data merupakan bagian vital dari suatu sistem informasi karena sistem ini menyediakan infrastruktur yang memungkinkan komputer-komputer dapat berkomunikasi satu sama lain. 


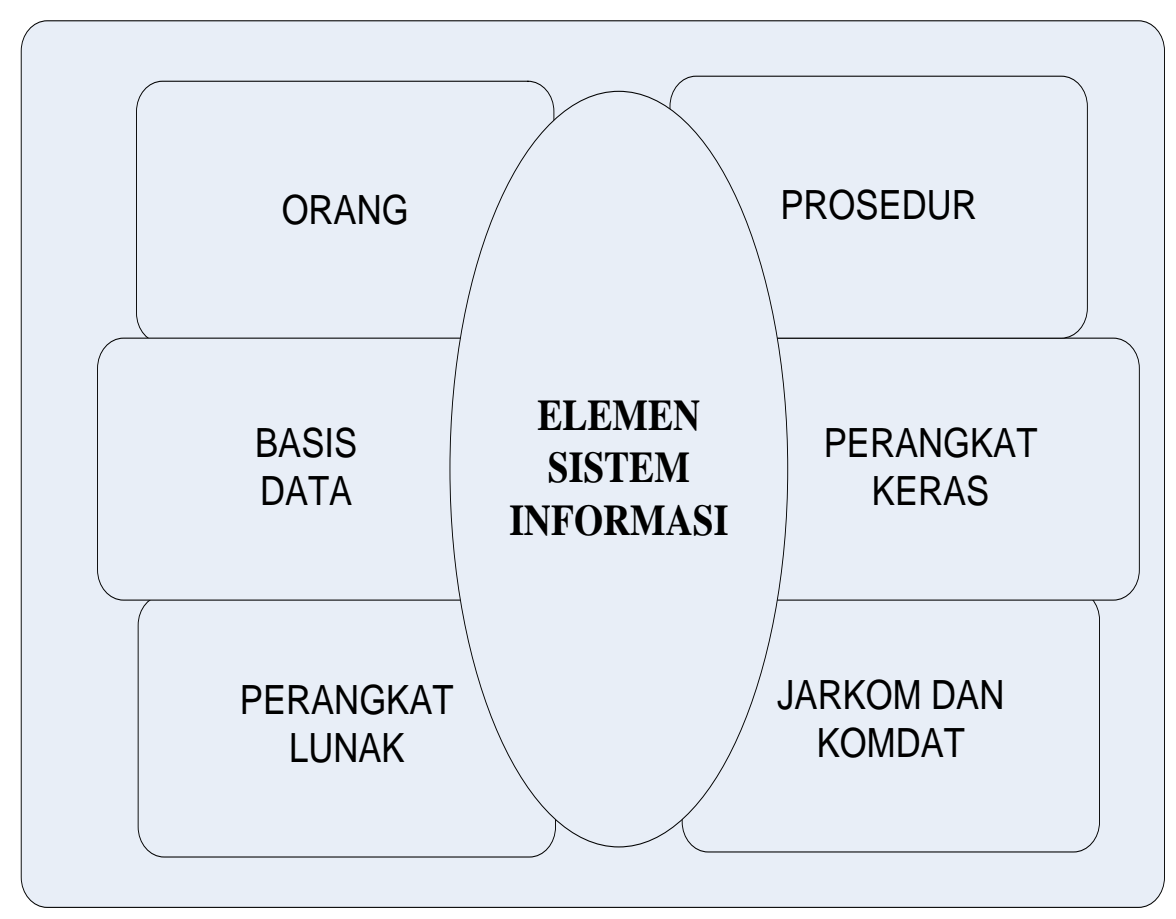

Gambar 2.1. Informasi Dalam Sistem Pengolahan

"Istilah sistem pengolahan transaksi (transaction processing system) digunakan untuk sistem informasi yang bertugas mengumpulkan data - data yang berkaitan dengan aktifitas aktifitas perusahaan, mengubah data - data tersebut menjadi informasi, dan membuat informasi tersebut dapat digunakan oleh pengguna onformasi oleh pengguna didalam dan diluar perusahaan (Raymond dan George, 2007)".

Menurut Ian Sommerville (2003), "Rekayasa perangkat lunak adalah disiplin ilmu yang membahas semua aspek produksi perangkat lunak, mulai dari tahap awal spesifikasi sistem sampai pemeliharaan sistem setelah digunakan". Pada defenisi ini ada dua istilah kunci:

a. Perekayasa membuat suatu alat bekerja. Mereka menerapkan teori, metode, dan alat bantu yang sesuai, selain itu mereka menggunkan dengan selektif dan selalu mencari solusi terhadap permasalahan. Walaupun tidak ada teori atau metode yang mendukung. Perekayasa juga menyadari behwa mereka harus bekerja dalam batasan organisasi dan keuangan, sehingga mereka berusaha mencari solusi dalam batasan - batasan ini.

b. Rekayasa perangkat lunak tidak hanya berhubungan dengan proses teknis dari pengembangan perangkat lunak tetapi juga dengan kegiatan seperti manajemen proyek perangkat lunak dan pengembangan alat bantu, metode, dan teori untuk menfukung produksi perangkat lunak.

\section{Konsep Sistem Informasi Akuntansi}


Berdasarkan Gelinas dan Oram (1996), "Sistem informasi akuntansi adalah suatu sub sistem khusus dari sistem informasi manajemen yang bertujuan mengumpulkan memproses, dan melaporkan informasi yang berhubungan dengan transaksi - transaksi keuangan” (p.16)

Produk dari akuntansi adalah laporan keuangan. Laporan keuangan ini berisi informasi yang menggambarkan kondisi dan kinerja suatu perusahaan. Informasi ini berguna untuk pengambilan keputusan (Syarif HD, 2009).

Umumnya laporan keuangan terdiri dari neraca (balance sheet), laporan laba-rugi (profit and loss statement), laporan perubahan modal, arus kas (cash flow statement) dan catatan atas laporan keuangan (notes of financial statement).

\section{Pemodelan Sistem Informasi}

Pemodelan dalam suatu rekayasa perangkat lunak merupakan suatu hal yang dilakukan di tahapan awal. Di dalam suatu rekayasa perangkat lunak sebenarnya masih memungkinkan tanpa melakukan suatu pemodelan, namun seiring dengan perkembangan kebutuhan akan informasi project yang akan dilaksanan hal itu tidak dapat lagi dilakukan dalam industri perangkat lunak. Dimana pemodelan ini akan mempengaruhi pekerjaan - pekerjaan dalam rekayasa perangkat lunak tersebut.

\section{Pemodelan Universal Modelling Language (UML)}

UML Merupakan bahasa pemodelan yang sangat komprehensif untuk siklus hidup modeling language. Yang telah menjadi standar di buat oleh OMG pada tahun 1997, yang dapat mengiringi kompleksitas suatu sistem yang real-time (apakah untuk sistem yang berskala besar, networking, pengadaan web, dan managemen data).

\section{Beberapa bentuk diagram UML}

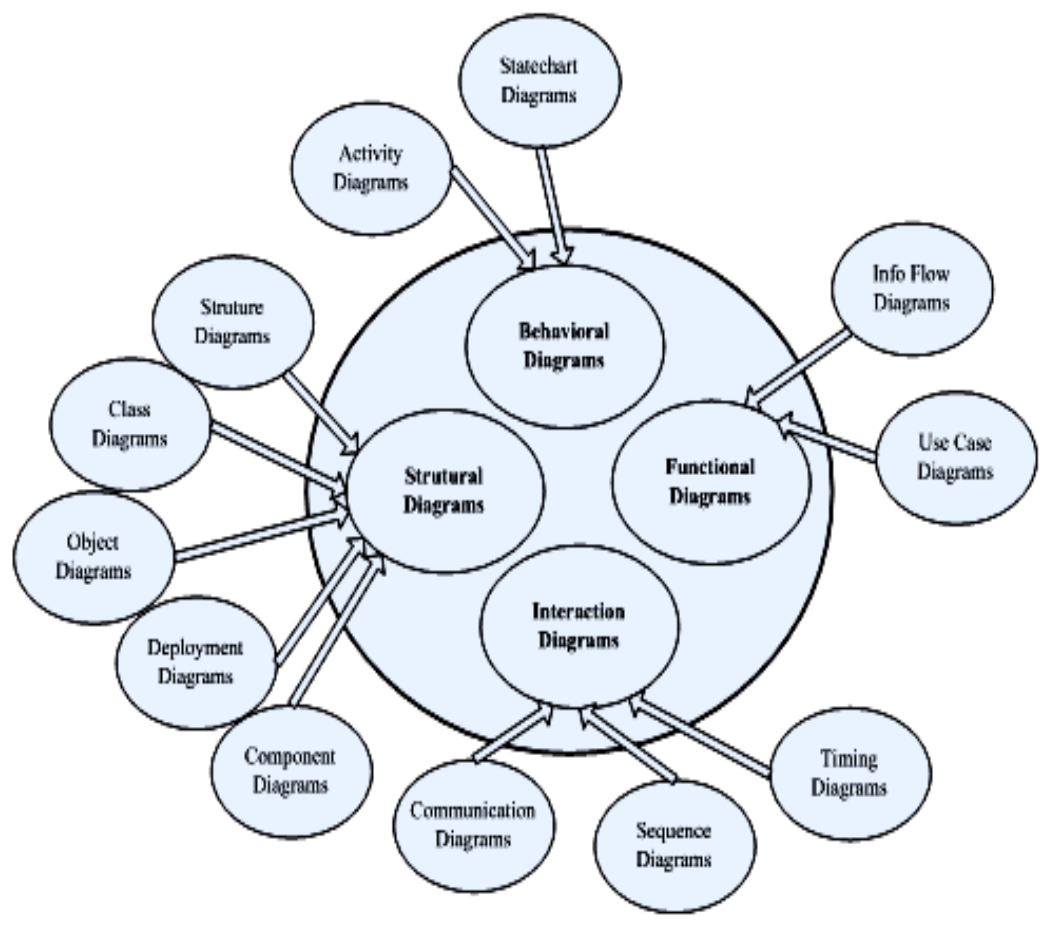


Gambar 2.2. UML Dalam Beberapa Bentuk Diagram

\section{METODOLOGI PENELITIAN}

Metodologi penelitian yang digunakan berkaitan dengan Pemodelan UML untuk perancangan Personal Software untuk manajemen keuangan. Metode yang digunakan mengikuti aturan dimana Tahapan-tahapan dan langkah-langkah yang akan dilakukan pada penelitian ini dirangkum dalam suatu kerangka kerja yang bertujuan untuk memberikan kemudahan dalam menyelesaikan permasalahan yang ada sehingga penelitian ini bisa berjalan dengan baik.

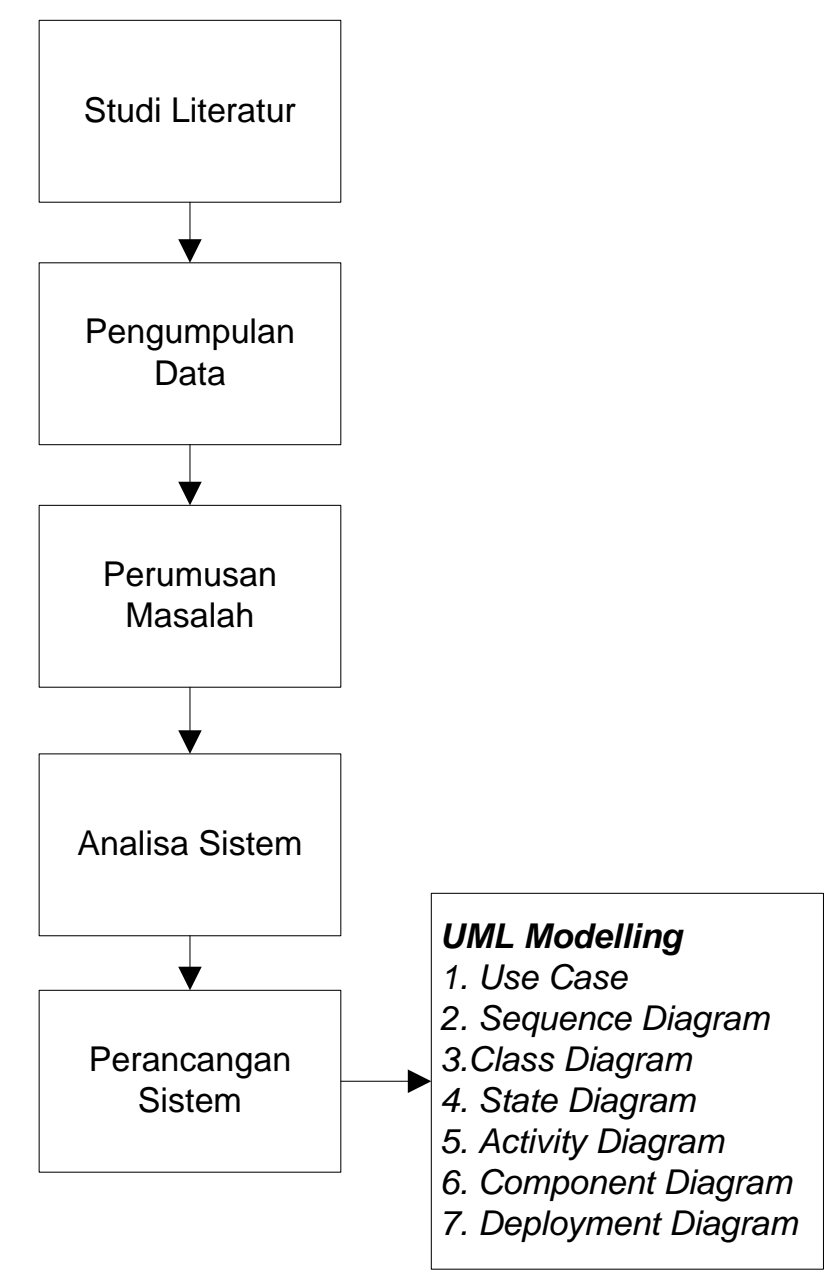

Gambar 3.1 Kerangka Konseptual Penelitian

\section{E. PEMBAHASAN}

\section{Analisa Permasalahan}


Secara periodik, perusahaan selalu mengeluarkan laporan keuangan yang dibuat oleh bagian akunting dan diberikan kepada pihak-pihak yang berkepentingan, misalnya pemerintah, kreditor, pemilik perusahaan dan pihak manajemen sendiri.

Ada banyak laporan keuangan yang dikeluarkan perusahaan, tetapi yang umum digunakan adalah : (1) Laporan Laba Rugi, (2) Neraca, (3) Laporan Arus Kas. Berikut adalah penjelasan ketiga laporan keuangan tersebut

1. Laporan Laba Rugi

Laporan Laba Rugi merupakan laporan/ringkasan kegiatan operasi perusahaan selama satu periode, umumnya adalah satu tahun dan berakhir 31 Desember xx. Untuk kepentingan terbatas, misalnya pada perusahaan public, perusahaan dapat mengeluarkan laporan untuk 3 bulan, 6 bulan atau 9 bulan.

2. Neraca

Neraca merupakan ringkasan posisi kekayaan perusahaan pada saat tertentu. Neraca berisi asset/kekayaan yang dimiliki perusahaan dan sumber dana untuk membiayai asset tersebut, yang berasal dari pihak di luar perusahaan (disebut kewajiban/liabilities) dan dari pemegang saham perusahaan (disebut modal/equity).

3. Laporan Arus Kas

Laporan Arus Kas merupakan ringkasan arus kas selama satu periode. Laporan ini menunjukkan perubahan arus kas yang terjadi karena kegiatan operasi, investasi dan financial sehingga posisi/saldo kas berubah.

Berdasarkan hasil analisis tersebut, maka dapat diketahui bahwa sistem yang layak untuk di implementasikan pada Personal Software untuk keperluan managemen keuangan saat ini adalah sistem akunting elektronik (E-Accounting System) dengan menggunakan berbagai fitur yang dapat digunakan sesuai dengan fungsinya.

\section{Rancangan Kerangka Sistem Melalui Pemetaan Unified Modeling Language (UML)}

Sesuai dengan metode OOAD (Object Oriented Analisys \& Design), perancangan sistem akan melewati beberapa tahap untuk mengetahui bagaimana sistem ini nantinya akan dibuat.

Sebagai sebuah notasi grafis yang relatif sudah dibakukan UML menawarkan banyak keistimewaan, terdapat tiga karakter penting yang melekat pada UML yaitu sketsa, cetak biru, 
dan bahasa pemograman. UML dibangun atas model 4+1 view (Process view, Design View, Deployment View, Implementation View dan Use Case View).

Umumnya sebuah sistem mempunyai sejumlah stakeholder, dari sini jelas kita sangat butuh banyak diagram dari berbagai sudut pandang. Dengan demikian tujuan utama dari banyaknya diagram ini adalah untuk menjelaskan bentuk jadi suatu sistem yang akan dibangun pada semua stakeholder yang terkait.

Dalam hal pemetaan sistem ini digunakan metode UML sesuai dengan penjelasan pada bagian sebelumnya. Dimana diagram yang akan merepresentasikan rancangan tersebut diantaranya:

1. Use Case

Use Case yang digunakan dalam perancangan diagram ini adalah abstraksi dari interaksi antara sistem yang akan diterapkan dengan actor (pengguna). Oleh karena itu sangat penting untuk menentukan abstraksi yang cocok, Use case disini akan menjelaskan 'apa' yang akan dikerjakan oleh aplikasi (software), bukan bagaimana aplikasi mengerjakannya

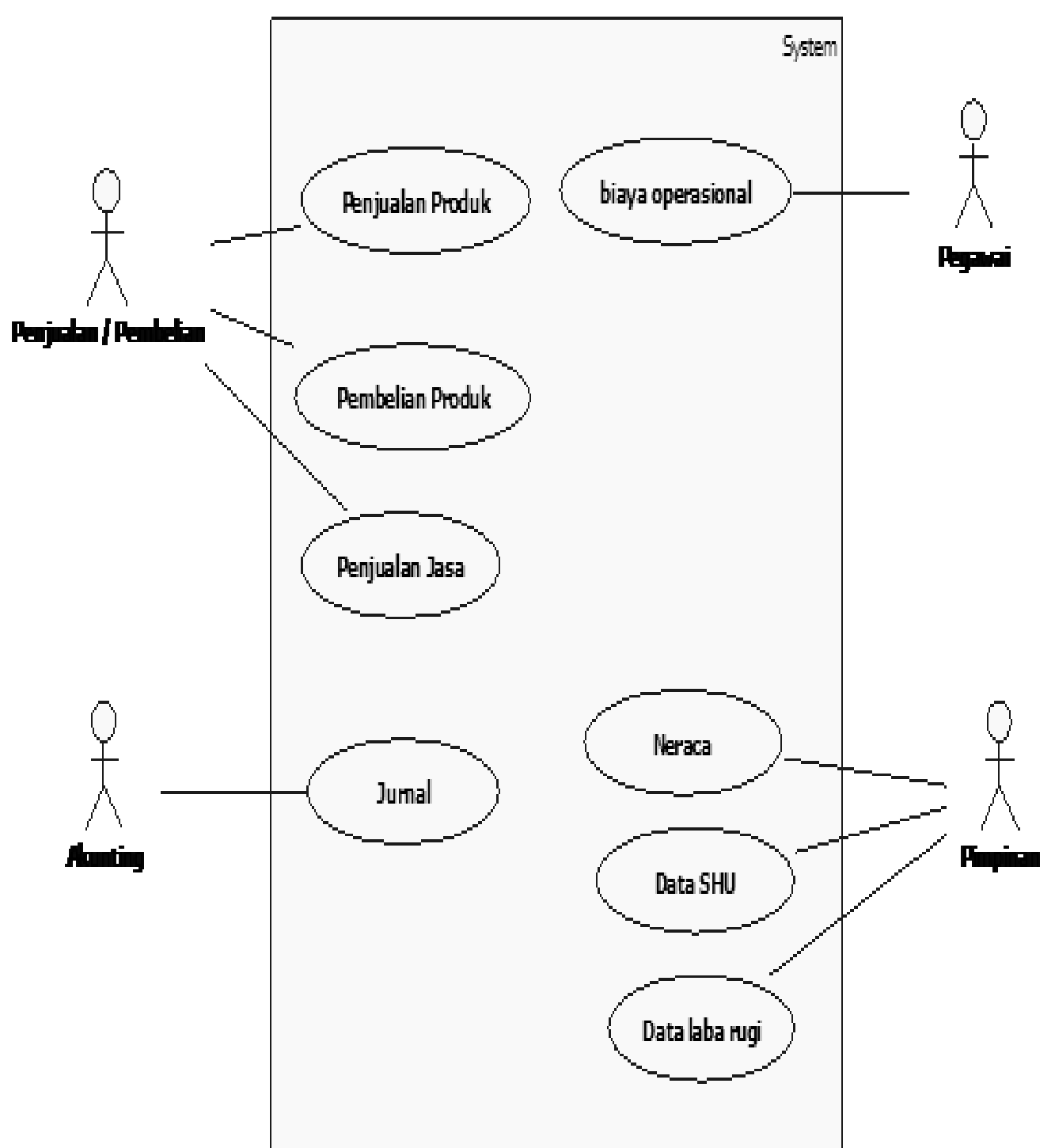


Gambar 4.1 Diagram Use Case Managemen Keuangan

Tabel 2.1 Skenario use case

\begin{tabular}{|c|c|c|}
\hline NO & AKTOR & SKENARIO \\
\hline 1. & $\begin{array}{l}\text { Bagian } \\
\text { Pembelian / } \\
\text { Penjualan }\end{array}$ & $\begin{array}{l}\text { Bertugas untuk megumpulkan barang - } \\
\text { barang yang akan di jual oleh } \\
\text { perusahaan, mendistribusikan barang } \\
\text { atau jasa yang diperlukan oleh } \\
\text { pelanggan. }\end{array}$ \\
\hline 2. & Pegawai & $\begin{array}{l}\text { Pegawai disini membantu dalam } \\
\text { operasional perusahaan untuk } \\
\text { menjalankan usaha baik dalam } \\
\text { mempersiapkan atau berhubungan } \\
\text { langsung dengan konsumen, dari tugas } \\
\text { yang dilakukan tersebut akan } \\
\text { menimbulkan sejumlah fee yang harus } \\
\text { dikeluarkan oleh perusahaan dalam } \\
\text { bentuk biaya operasional. }\end{array}$ \\
\hline 3. & Akunting & $\begin{array}{l}\text { Memilki tugas untuk meng - entrikan } \\
\text { data transaksi untuk di buatkan kan } \\
\text { kedalam buku jurnal, dari jurnal } \\
\text { tersebut akan dibuatkan data - data } \\
\text { yang akan dipergunakan oleh bagian } \\
\text { pimpinan untuk dijadikan dasar atas } \\
\text { kebijakan yang akan ditentukan. }\end{array}$ \\
\hline 4. & Pimpinan & $\begin{array}{l}\text { Pimpinan dalam hal ini di jelaskan } \\
\text { menerima sejumlah data laporan dari } \\
\text { bagian yang telah ditentukan dalam } \\
\text { bentuk data Neraca, Data Sisa Hasil } \\
\text { Usaha (SHU), dan Data Laba Rugi. } \\
\text { Sebagai dasar pengambilan kebijakan }\end{array}$ \\
\hline
\end{tabular}




\begin{tabular}{|l|l|l|}
\hline & & suatu keputusan. \\
\hline
\end{tabular}

\section{Sequence Diagram}

a. Login

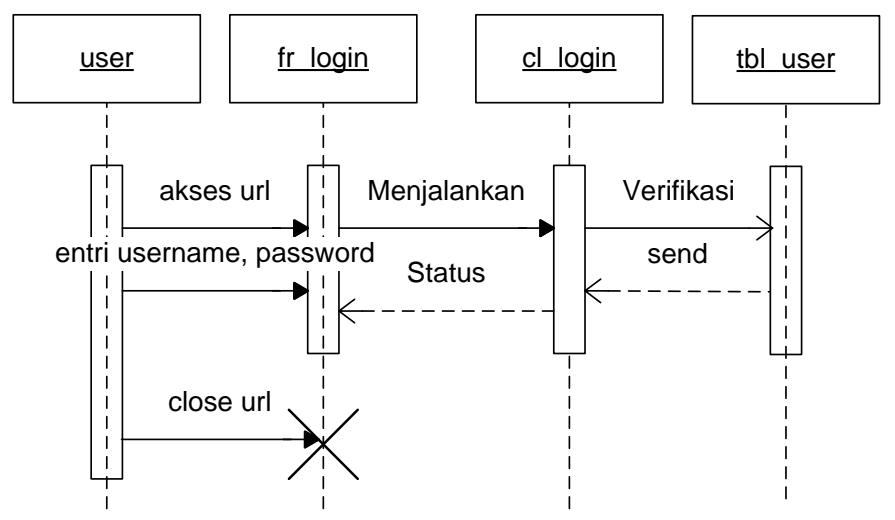

Gambar 4.2 Login Sequence diagram

b. Profil Perusahaan

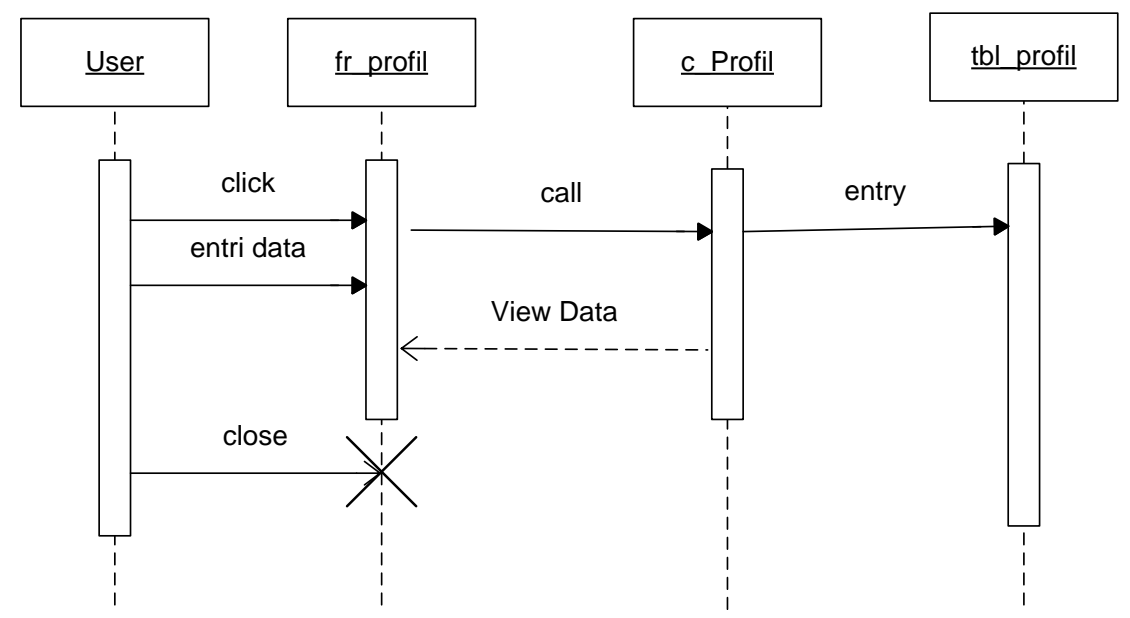

Gambar 4.3 Profil Sequence Diagram

c. Input Data Perkiraan Awal 


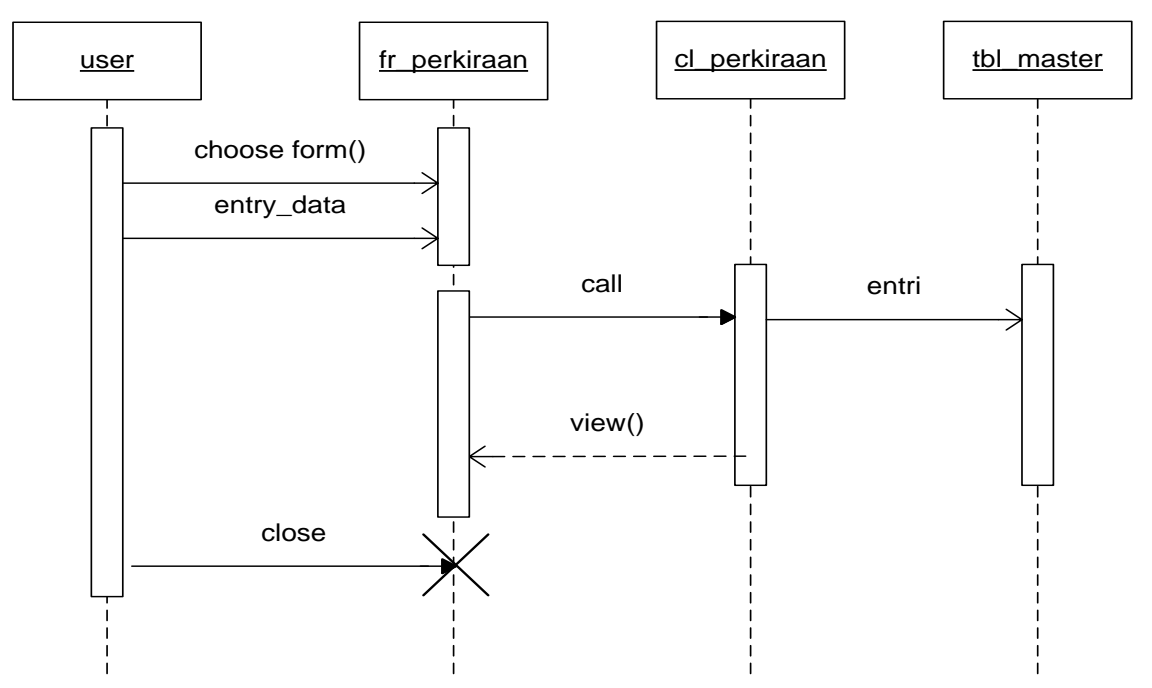

Gambar 4.4

Sequence Diagram Untuk Perkiraan

d. Entri data jurnal umum

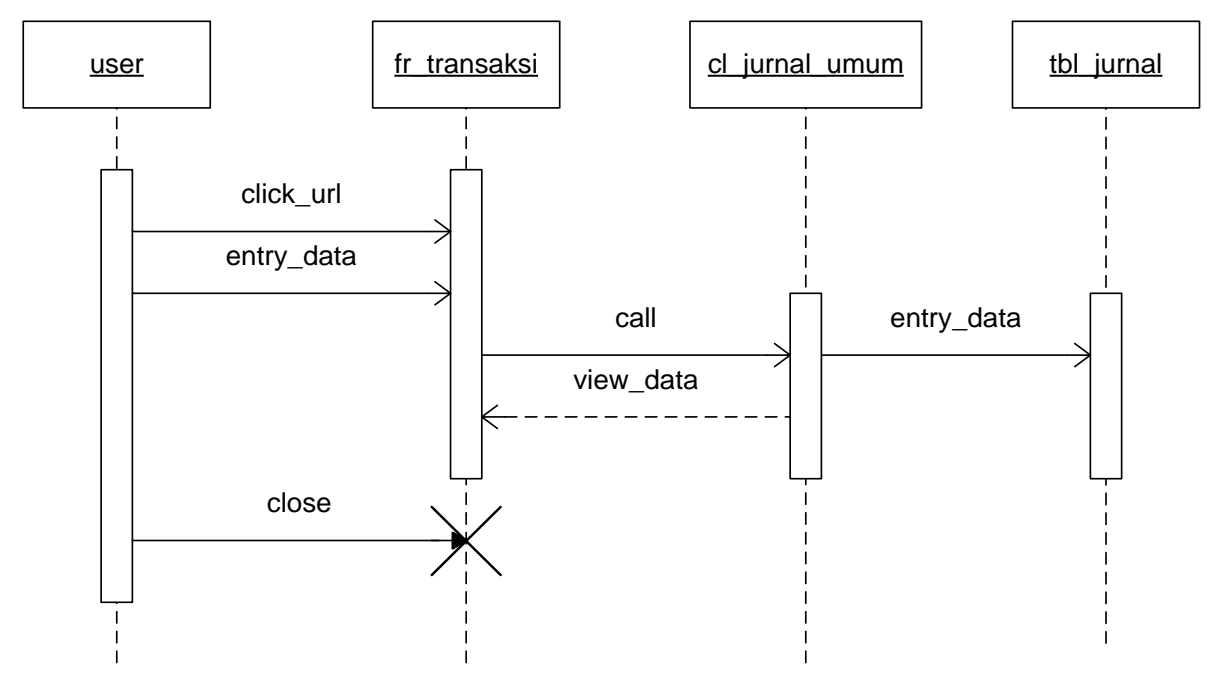

Gambar 4.5 Sequence Diagram Untuk Entri Data Jurnal Umum

e. Entri data jurnal kas keluar 


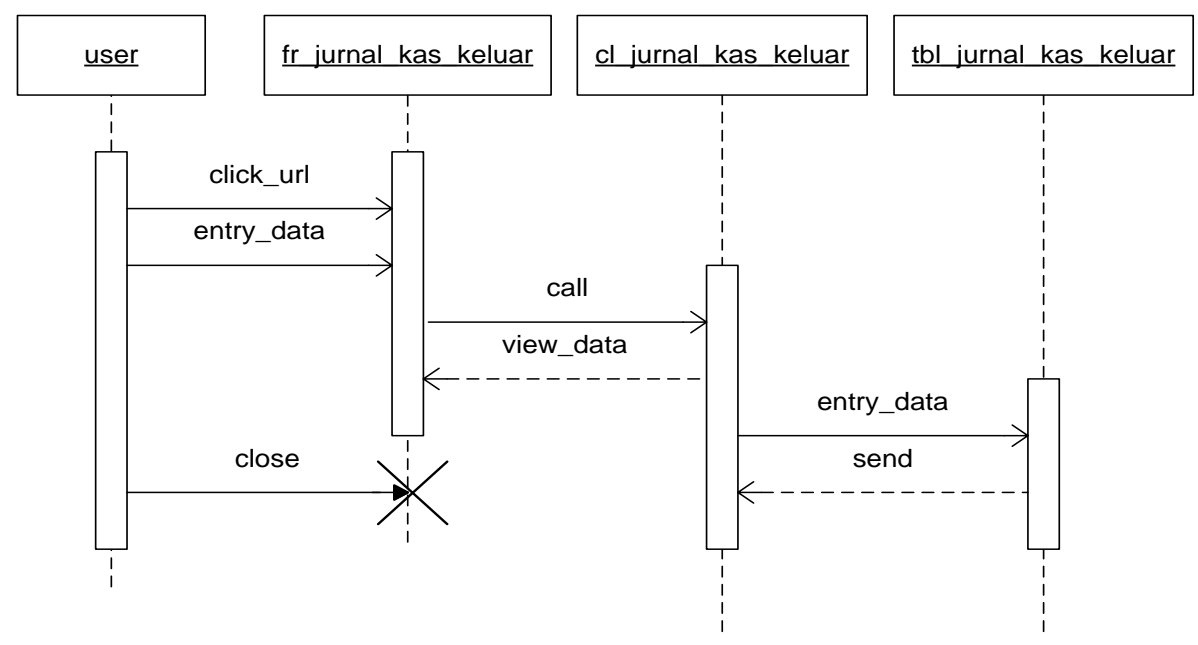

Gambar 4.6 Sequence Diagram Untuk Jurnal Kas Keluar

f. Tampilan halaman data Posting

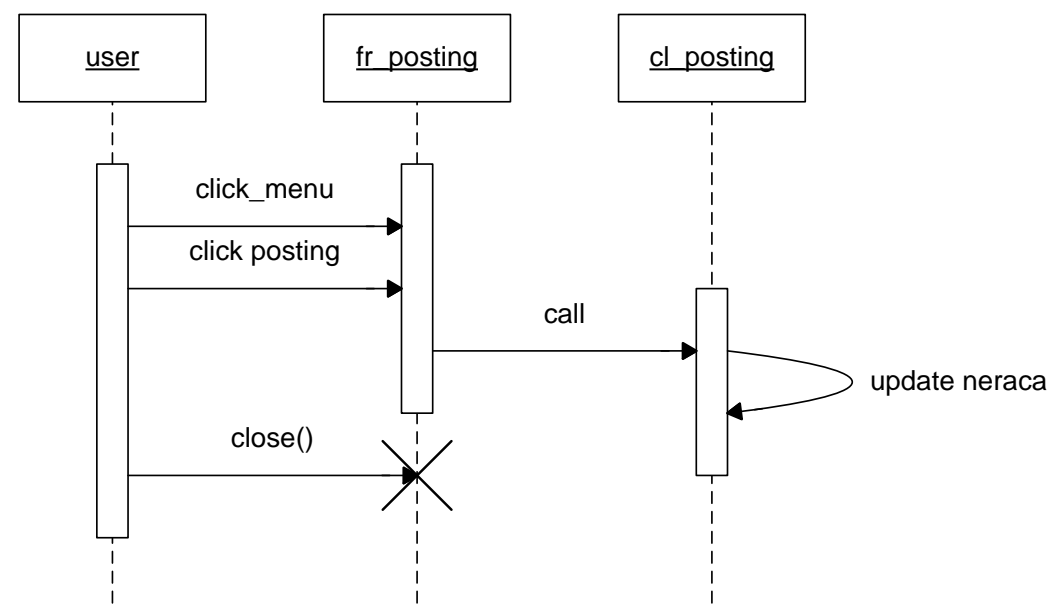

Gambar 4.7 Sequence Diagram untuk Posting

g. Laporan Buku Jurnal 


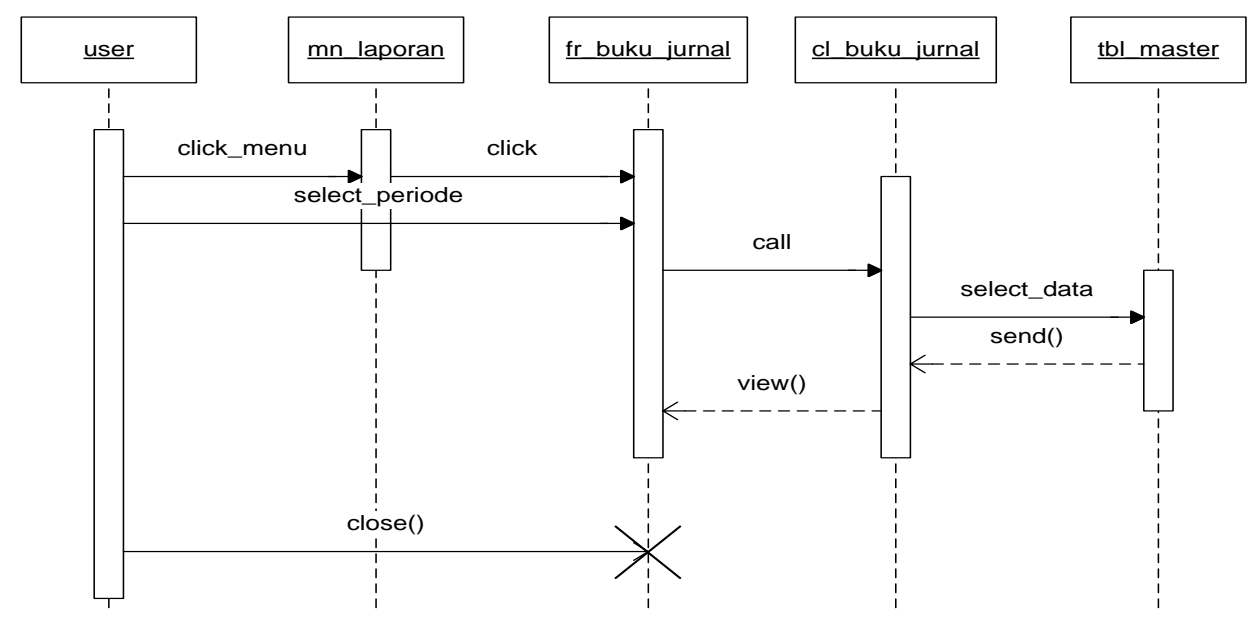

Gambar 4.8 Sequence Diagram Untuk Laporan Buku Jurnal

h. Laporan Neraca Percobaan

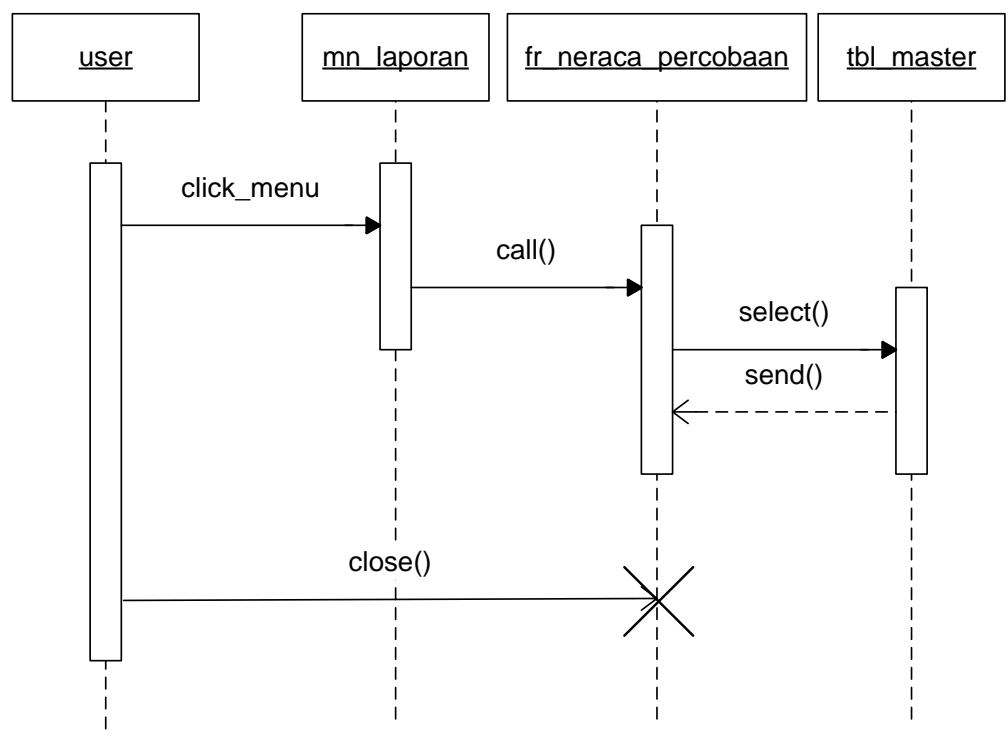

Gambar 4.9 Sequence Diagram untuk Laporan Neraca Percobaan

i. Laporan Sisa Hasil Usaha (SHU) 


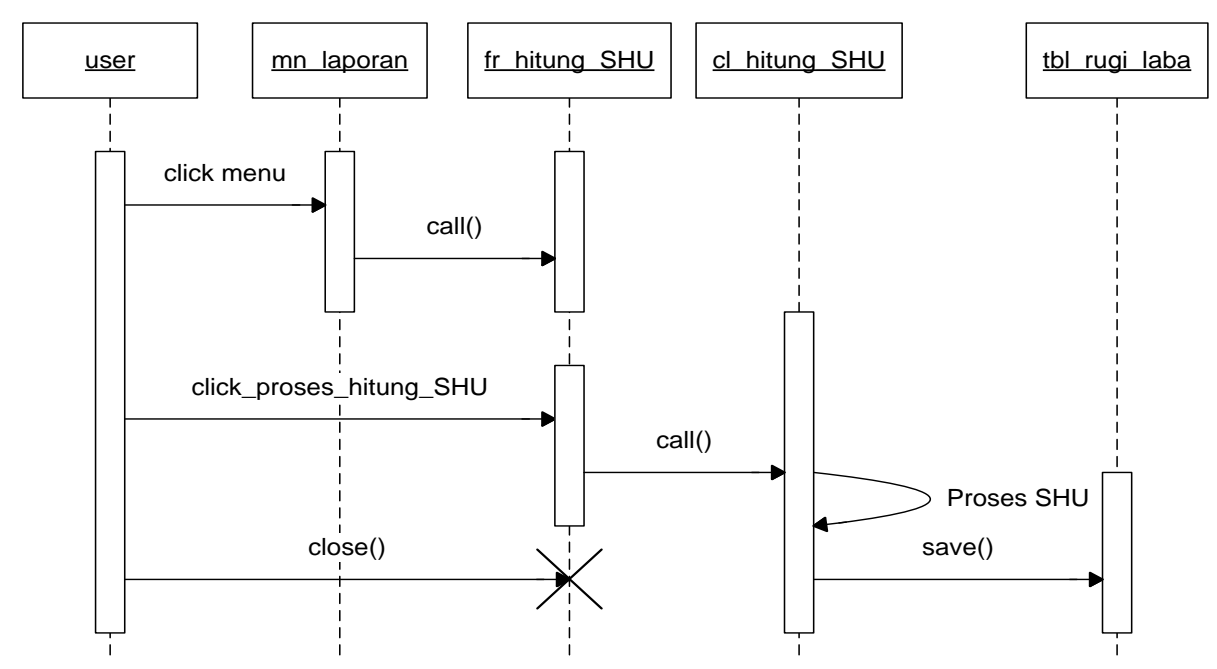

Gambar 4.10 Sequence Diagram Untuk Laporan SHU

j. Sequence Diagram Laporan Rugi Laba

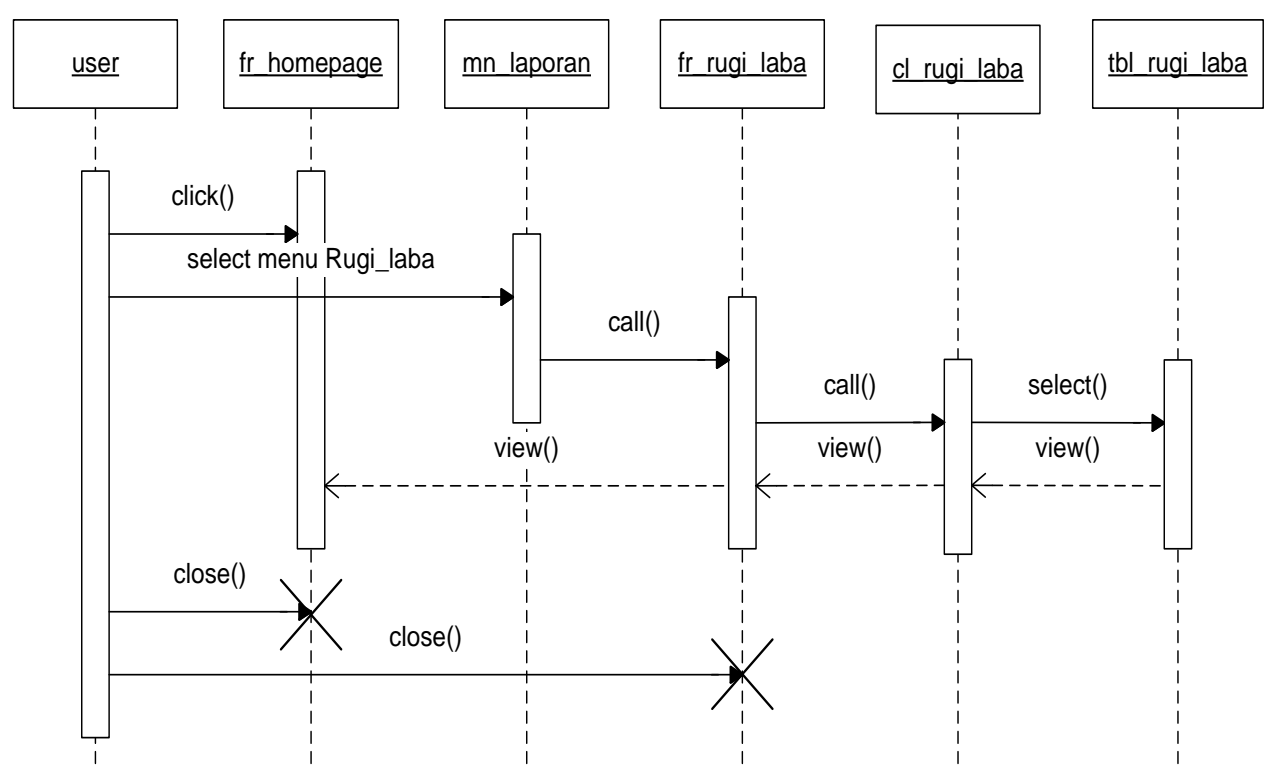

Gambar 4.11 Sequence Diagram Laporan Rugi Laba

k. Sequence Diagram Laporan Neraca 


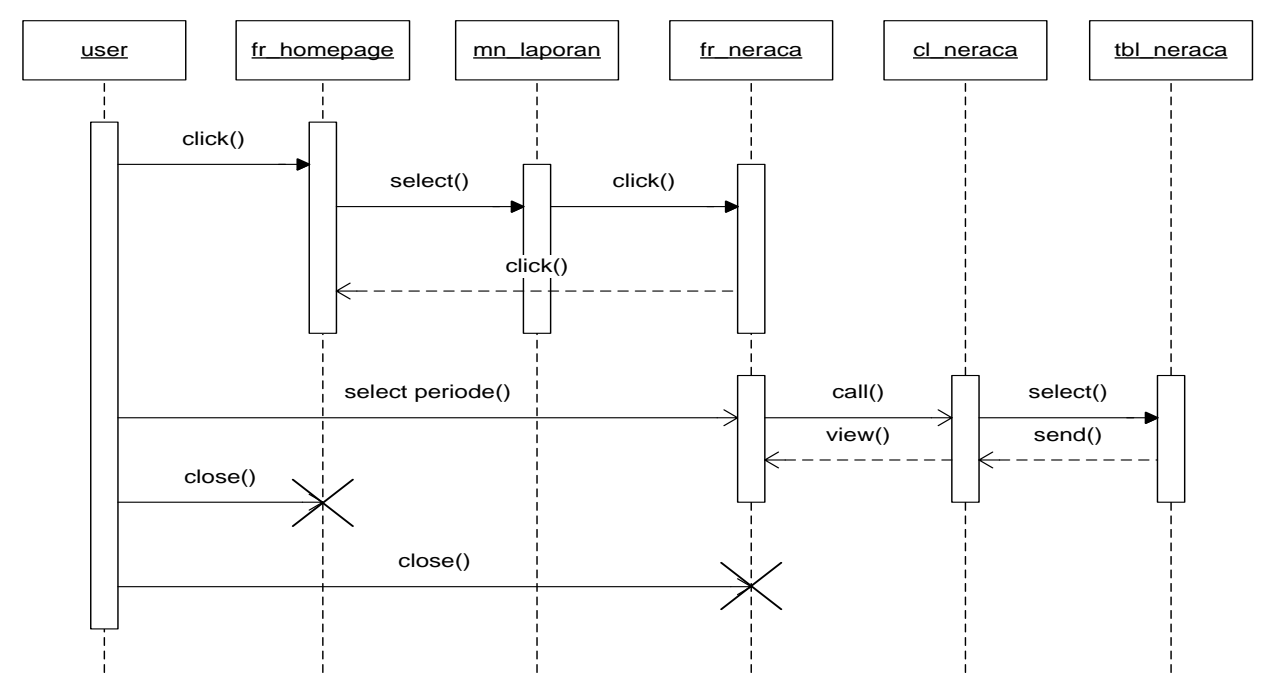

Gambar 4.12 Sequence Diagram Untuk Laporan Neraca

1. Sequence Diagram Untuk Logout

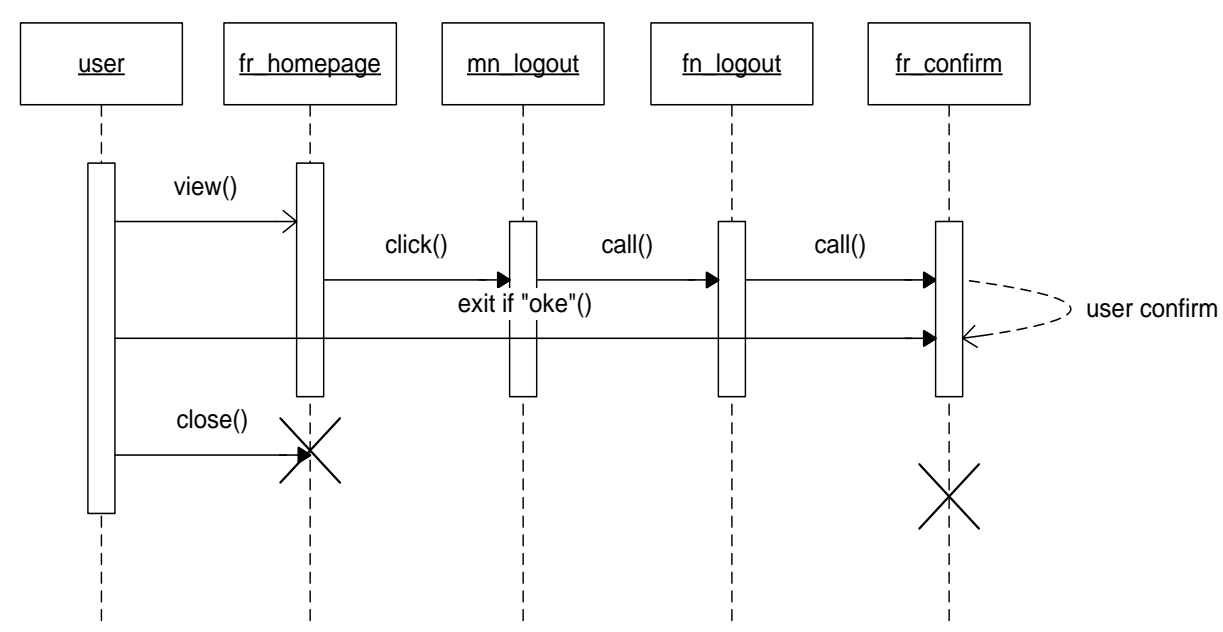

Gambar 4.14 Sequence Diagram Untuk Proses Logout

\section{Class Diagram}

Pada class diagram ditunjukkan terdapat beberapa class yang merupakan transformasi dari berbagai kebutuhan yang akan diproses oleh e-accounting systems. Class tersebut dapat dibagi dalam beberapa proses utama yang akan diterapkan pada sistem, dimana dari tiap tiap class menjelaskan beberapa attribute dan operation yang ada. 


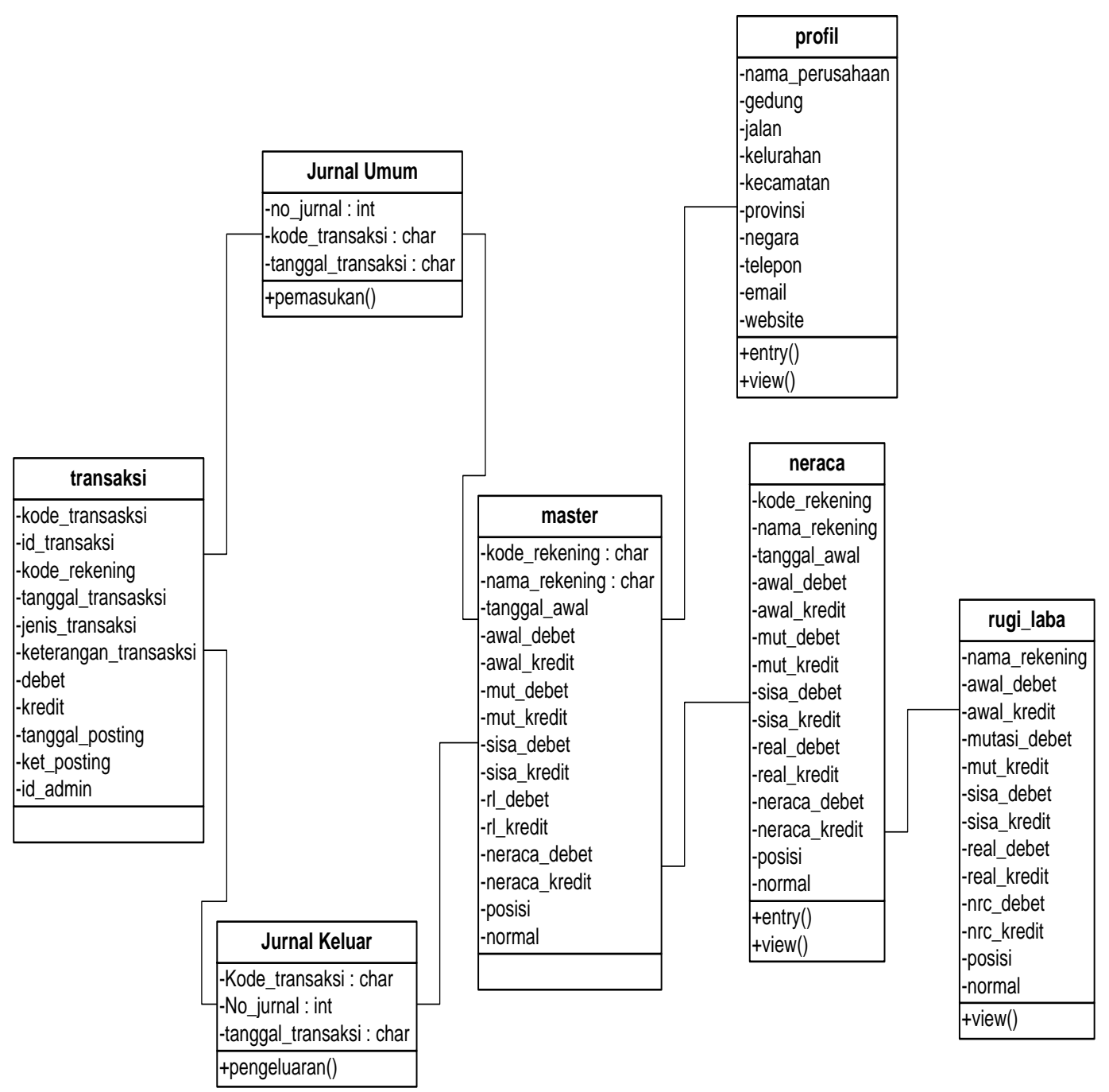

Gambar 4.15 Class Diagram Aplikasi Managemen Keuangan

\section{State Diagram}

State chart diagram adalah suatu diagram yang menggambarkan daur hidup (behavior pattern) dari sebuah objek, dimulai dari objek tersebut diinisialisasi sampai dengan objek tersebut selesai di eksekusi. Dalam hal ini state diagram menggambarkan transisi dan perubahan keadaan (dari satu sate ke state lainnya). 


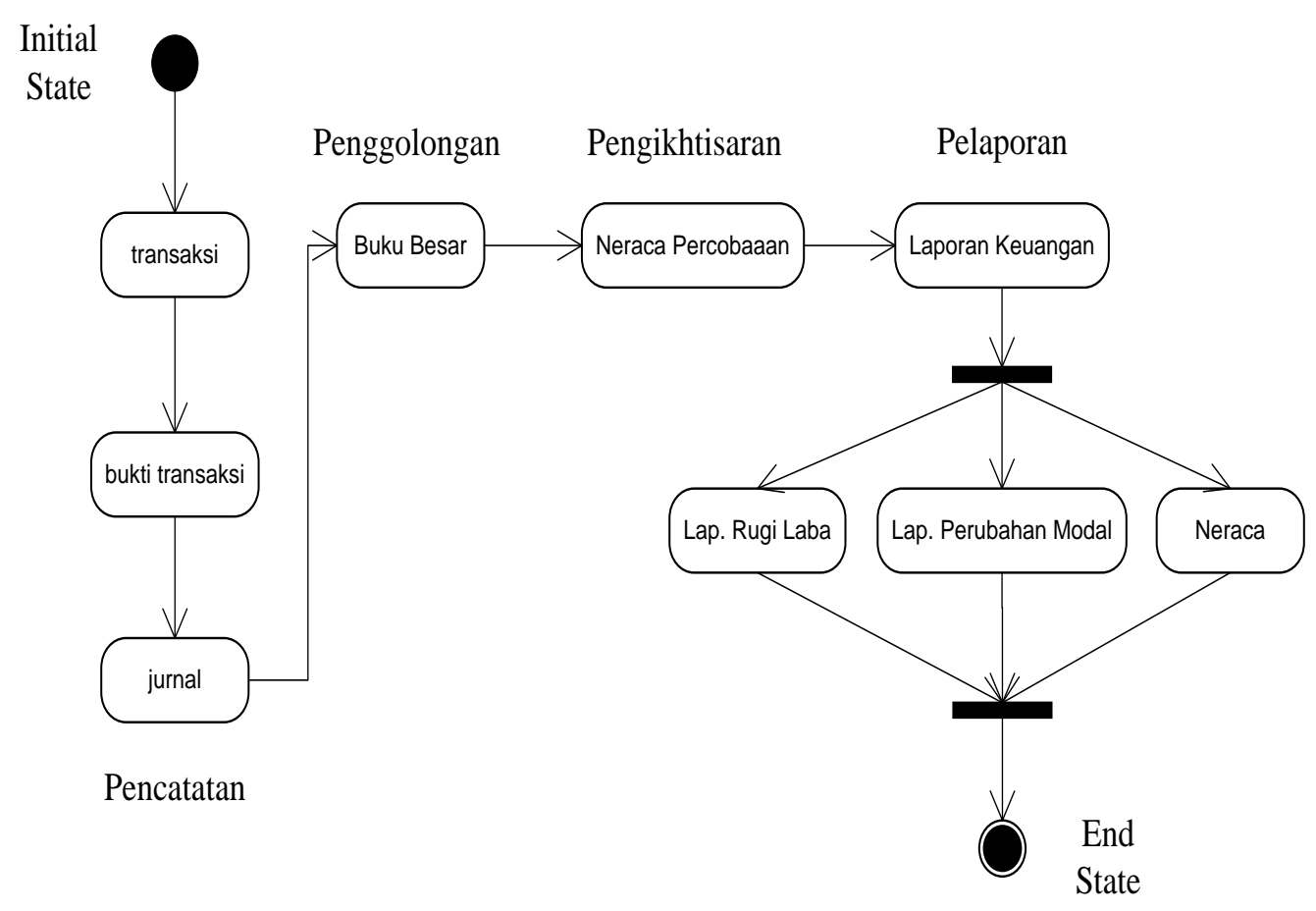

Gambar 4.16 State Diagram Untuk Manajemen Keuangan

\section{Activity Diagram}

Untuk teknik mendeskripsikan logika prosedural, proses bisnis dan aliran kerja dalam banyak kasus digunakan activity diagram. Beberapa diagram yang disajikan berikut merupakan sejumlah activity diagram yang di kelompokkan berdasarkan jumlah procedural yang terdapat sistem akuntansi keuangan ini.

a. Activity diagram proses login 


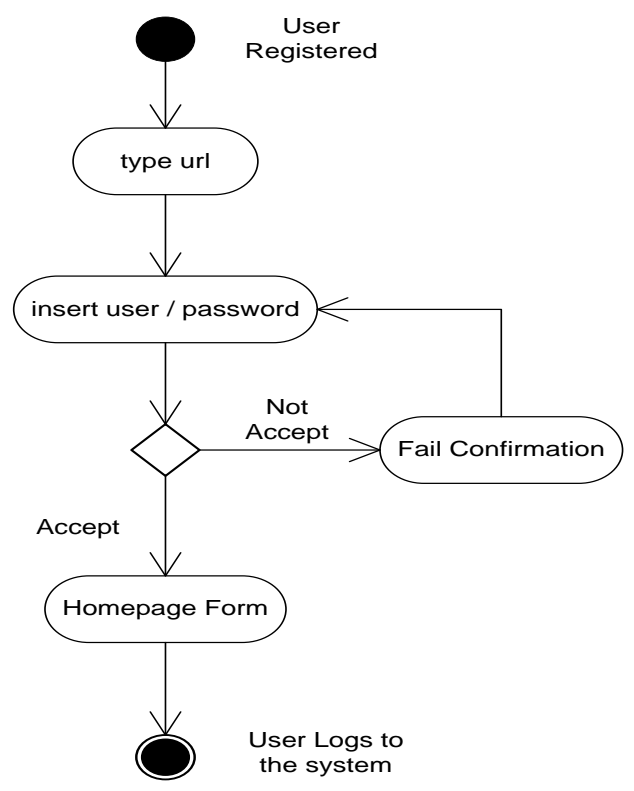

Gambar 4.17 Activity Diagram Untuk Proses Login

b. Activity diagram Proses penyesuaian aplikasi sistem

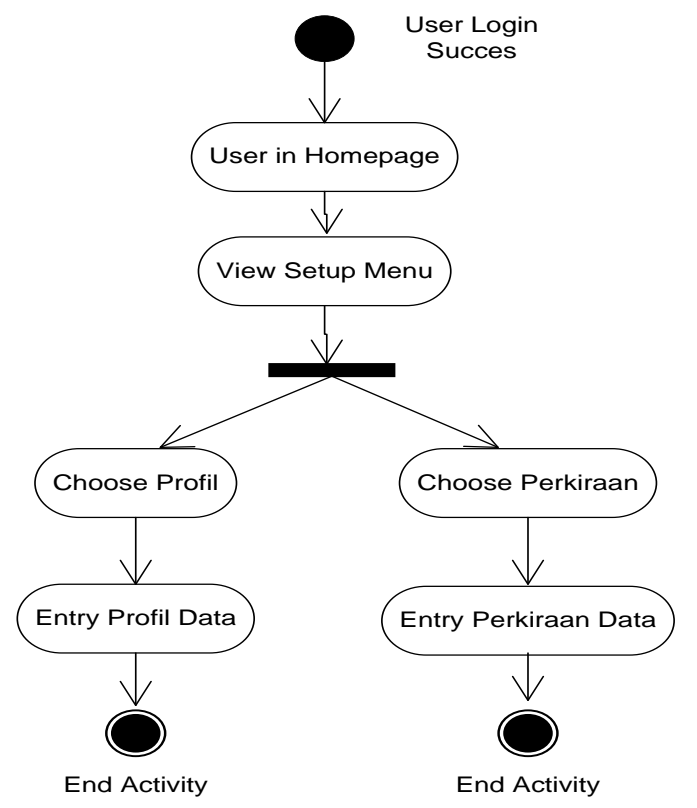

Gambar 4.18 Activity diagram Untuk Setup Sistem

c. Activity Diagram untuk Pelaporan 


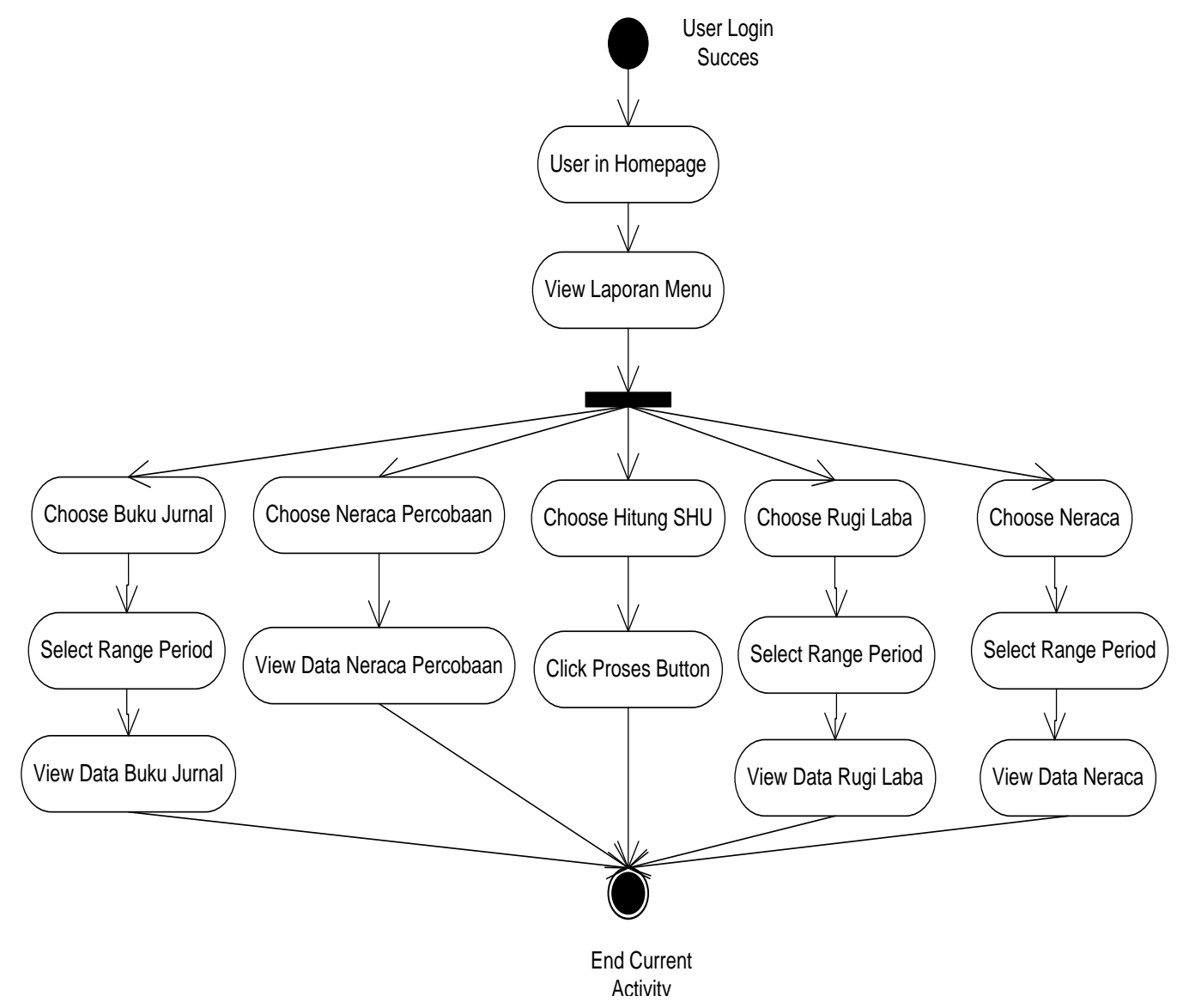

Gambar 4.19 Activity Diagram Sistem Pelaporan

\section{Component Diagram}

Sesuai dengan gambar yang ditunjukkan berikut, component yang di gambarkan adalah beberapa component yang terdapat dalam perancangan riil dari sistem e-accounting online. Component bisa diakses melalui interface-nya yaitu koleksi operasi - operasi yang berelasi antar satu component dengan component lainnya. 


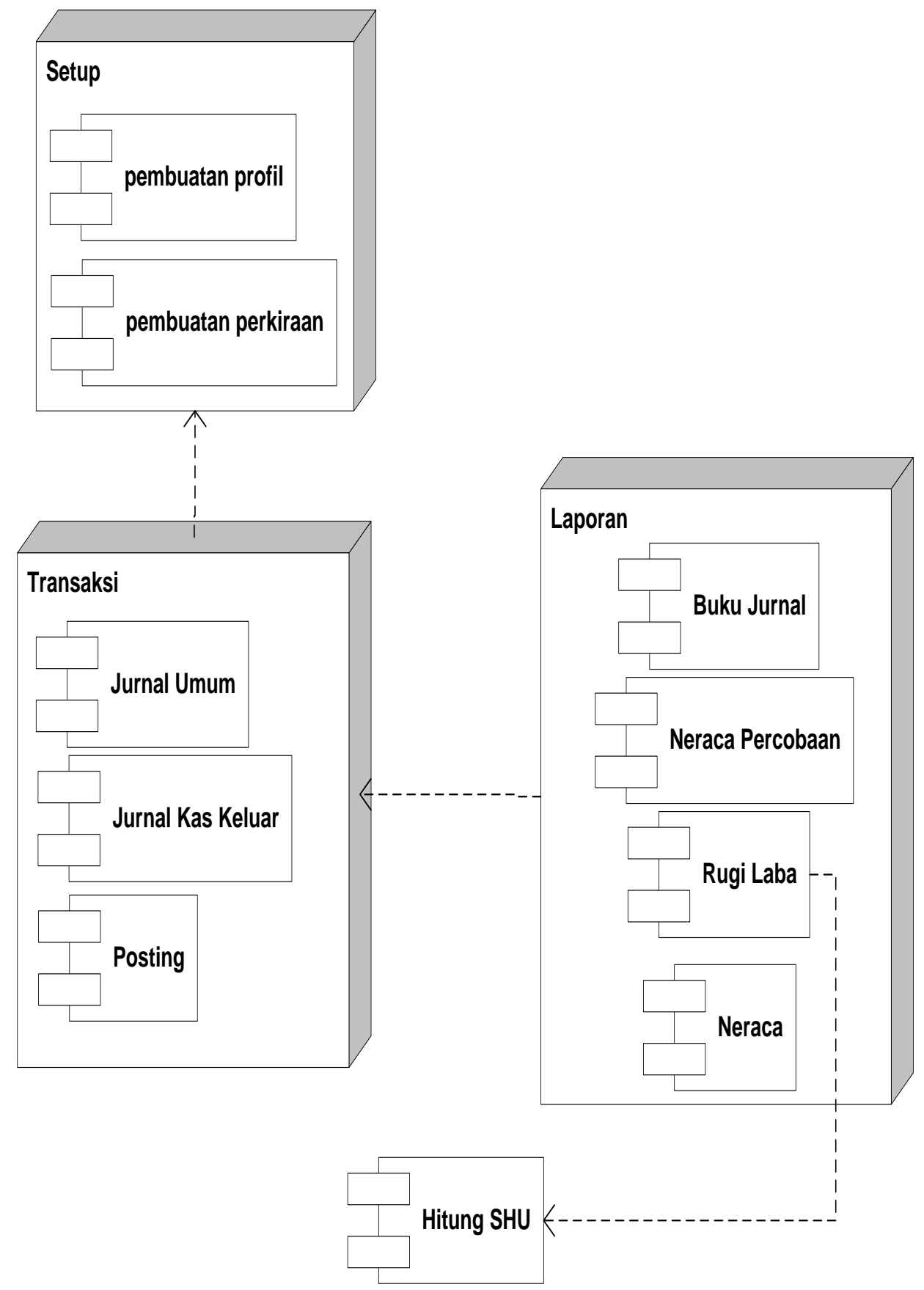

Gambar 4.21 Component Diagram E-Accounting Online

\section{Deployment diagram}

Deployment diagram menunjukkan tata letak sebuah sistem secara fisik, menampakkan bagian - bagian software yang berjalan pada bagian - bagian hardware. 


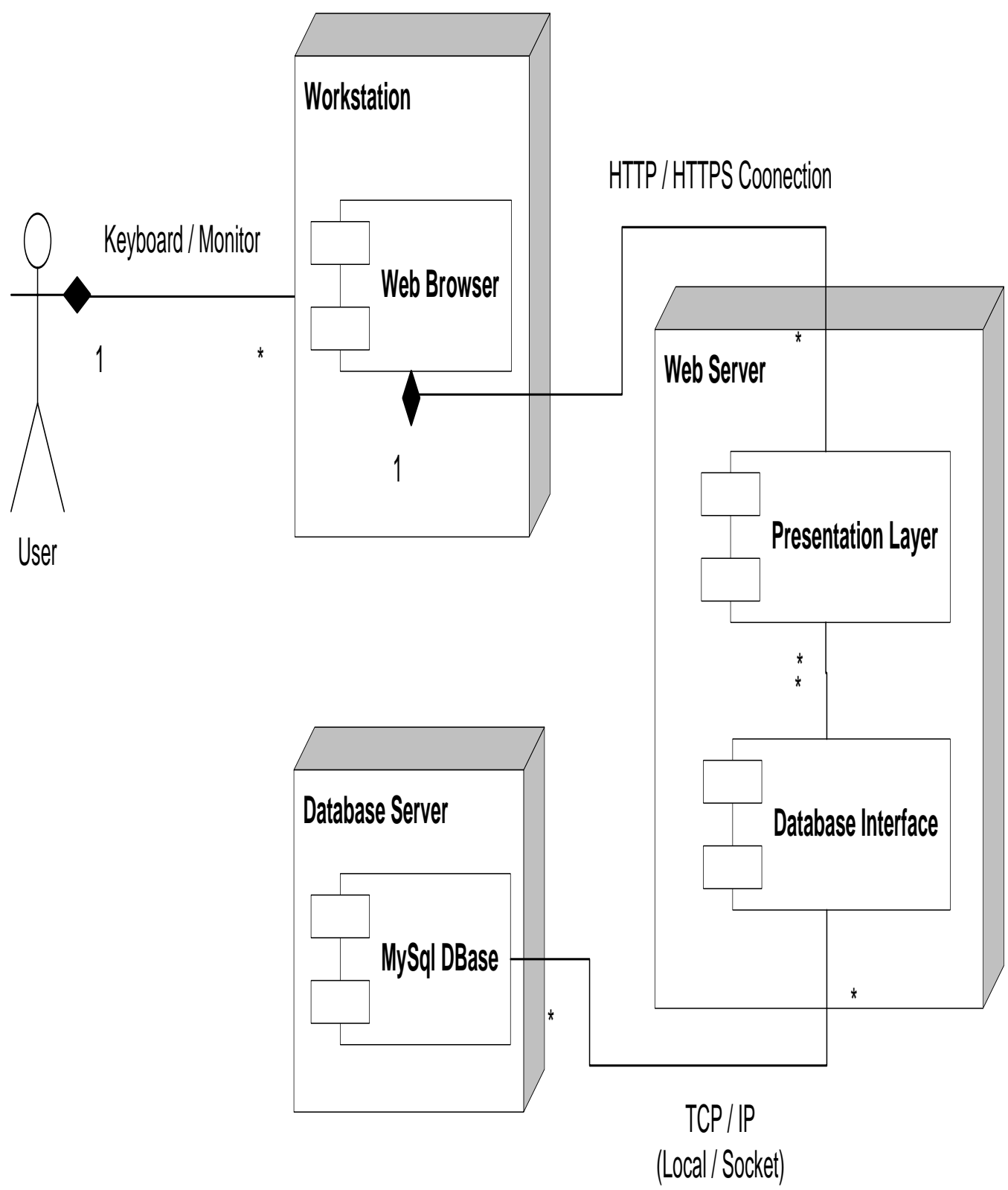

Gambar 4.22 Deployment Diagram

\section{F. KESIMPULAN}

Adapun kesimpulan yang dapat diambil adalah sebagai berikut:

1. Dari analisis yang dilakukan dengan menelaah dari keigatan - kegiatan umum yang terdapat pada proses manual dari sistem manajemen keuangan dan digambarkan menggunakan beberapa diagram yang disediakan oleh pemodelan dengan metode Unified Modelling Language (UML).Dan dialihkan kedalam rancangan software yang disesuaikan dengan proses sesungguhnya dengan bahasa pemograman PHP. 
2. Rancangan yang diajukan dari hasil analisis tersebut merupakan aplikasi berbasis web yang menyediakan fasilitas menajemen keuangan yang dapat di terapkan pada perusahaan perusahaan ber - orientasi profit, baik keuangan maupun jasa. Dengan menggunakan dan menerapkan hasil dari rancangan aplikasi ini diharapkan dapat mempermudah proses pengelolaan keuangan yang biasa dilakukan manual menjadi sistem yang terkomputerisasi.

3. Dengan adanya analisa permasalahan dari proses yang umum dan dapat ditransformasikan menjadi bahasa yang dapat digunakan oleh developer softwarehouse ataupun programmer diharapkan ilmu yang disajikan dalam laporan thesis ini bisa bermanfaat.

\section{G. SARAN}

Saran yang diberikan atas hasil penulisan karya ilmiah ini adalah:

1. dengan meningkatnya peranan teknologi informasi dalam segala bidang usaha, diharapkan adanya sistem manajemen keuangan yang lebih privasi dan terjaga keamanannya, dilain sisi layanan sistem informasi manajemen keuangan tersebut dapat dinikmati dimana saja secara bebas.

2. Perlu adanya personalisasi untuk beberpa fitur dari aplikasi perangkat lunak agar langsung dapat diarsipkan oleh masing - masing perusahaan yang menggunakan layanan aplikasi ini. Dalam pemodelan UML perlu dikembangkan dalam beberapa bentuk bahasa yang lebih bisa dipahami oleh masing - masing pihak, baik itu pengembang yang lebih berkomunikasi bahasa komputer maupun pihak pemakai yang lebih berbahasa alami.

\section{DAFTAR PUSTAKA}

\section{Bahan Buku Bacaan}

Gregor Engels, Reiko Heckel, and Stefan Sauer. (2013). "UML - A Universal Modelling Language?" University of Paderborn, Dept. of Computer Science D 33095 Paderborn, Germany, February 2013,

Xiaoming Zhong, Nazim H. Madhavji, Khaled El Eman. (2000). "Critical Factors Affecting Personal Software Processes" McGill Unersity, University of Otago, National Research Council, Canada, December 2000,

Bruce Powel Douglass. (2013). "Telelogic Real-Time UML" Chief Evangelist Telelogic, www.ilogix.com, 
Ian Sommerville (2003). "Software Engineering (Rekayasa Perangakat Lunak). Edisi 6, jilid 1 ”. Penerbit Erlangga, Jakarta, September 2003,

Adi Nugroho (2009). "Rekayasa Perangkat Lunak Menggunakan UML dan Java" Penerbit ANDI Yogyakarta, Yogyakarta, Agustus 2009,

Raymond McLeod, Jr., Goerge O. Schell. (2007). "Sistem Informasi Manajemen (Edisi Kesembilan)" Pearson Prentice Hall, Inc., New Jersey (2004), Alih Bahasa Oleh PT. Indeks, Jakarta, 2007,

Verdi Yasin, S.Kom., M.Kom. (2012). "Rekayasa Perangkat Lunka Berorientasi Objek. Pemodelan, Arsitektur dan Perancangan (Modeling, Architecture and Design)" Penerbit PT. Mitra Wacana Media, Jakarta 2012,

Grady Booch, James Rumbaugh, an Ivar Jacosin. (2013). "The Unified Modeling Language Guide" Addison, Wesley, 2013,

Zahoor Ul Islam, and Xianzhong Zhou. (2011). "Software Process Improvement Framework for Software Outsourcing Based on CMMI" University of Gothenburg, Chalmers University of Technology Department of Computer Science and Engineering, SE-412 96, Gothenburg, Sweden, 2011,

Akhmad Haerudin (2010), "Perancangan Aplikasi Penjadwalan Pengiriman Sms Dengan J2me”, Jurnal Program Studi Teknik Informatika, Fakultas Ilmu Komputer, Universitas Mercu Buana, Jakarta, 2010. 